\title{
Keefektifan model PBL, PJBL, dan inquiry pendekatan saintifik untuk meningkatkan hasil belajar IPS SMP
}

\section{Effectiveness model PBL, PJBL and inquiry scientific approach to improve learning outcomes social studies in junior high school}

\author{
Riko Septiantoko ${ }^{\text {a, }}{ }^{*}$, Muhsinatun Siasah $\mathbf{M}^{\mathbf{b}, 2}$, \\ a, $b$ Program Studi Pendidikan IPS, Program Pascasarjana, Universitas Negeri Yogyakarta \\ ${ }^{1}$ richo_02@yahoo.com, ${ }^{2}$ muhsinsiasah@gmail.com \\ *korespondensi penulis
}

\section{Informasi artikel \\ Kata kunci: \\ Model Problem \\ Based Learning, \\ Model Project \\ Based Learning, \\ Model Inquiry,}

Hasil Belajar IPS

Penelitian ini bertujuan untuk mengetahui: (1) perbedaaan hasil belajar IPS antara siswa yang belajar dengan model Problem Based Learning, Project Based Learning, dan Inquiry; (2) hasil belajar siswa yang belajar dengan model Inquiry dengan model Problem Based Learning; (3) hasil belajar siswa yang belajar dengan model Problem Based Learning dengan model Project Based Learning; (4) hasil belajar siswa yang belajar dengan model Inquiry dengan model Project Based Learning. Populasi Penelitian adalah siswa SMP di Kabupaten Bantul dengan sampel SMP Negeri 1 Imogiri, SMP Negeri 1 Sewon, dan SMP Negeri 3 Bantul, dipilih secara Purposive Random Sampling. Teknik pengumpulan data menggunakan tes yang diuji dengan validitas isi dan validitas konstruk. Normalitas data diuji dengan rumus KolmogorofSmirnov, dan homogenitas diuji dengan Levene-Test. Teknik analisis data hasil penelitian menggunakan One way Anova. Hasil penelitian: (1) terdapat perbedaan hasil belajar antara model Problem Based learning, Project Based Learning, dan Inquiry (2) hasil belajar siswa dengan model Inquiry lebih tinggi dibandingkan dengan model Problem Based Learning (3) hasil belajar siswa dengan model Problem Based Leaning lebih tinggi dibandingkan dengan model Project Based Learning (4) Hasil belajar siswa yang belajar dengan model Inquiry lebih tinggi dibandingkan model Project Based Learning.

\section{Keywords:}

Problem Based learning, Project Based Learning, Inqury, Learning outcomes of Social studies

\section{ABSTRACT}

This study aims to reveal. (1) the difference between the results of Social studies among students who studied with Problem-Based Learning model, Project-Based Learning model, and Inquiry model, (2) Learning outcomes of students who learn the Inquiry model higher than those studied by the Problem Based Learning model, (3) Learning outcomes of students who learn by Problem-Based Learning model higher than those studied by the Project-Based Learning model, (4) Learning outcomes of students who learn by Inquiry model higher than those studied by the Project-Based Learning model. Population research is a Junior High School students in Bantul with selected sample SMP Negeri 1 Imogiri, SMP Negeri 1 Sewon, and SMP Negeri 3 Bantul selected used Purposive Random Sampling. Data collection technique used tests and observations that have been tested by content validity and construct validity. Normality of the data was tested by formula Kolmogorof-Smirnov and homogeneity tested by Levene-Test. Data were analyzed of research data using One way Anova. The results of research are as follow. (1) There were differences in learning outcomes of social studies model Problem-Based Learning, Project-Based Learning, and Inquiry. (2) Learning outcome of social studies who learn by Inquiry model was higher than those studied by the Problem-Based Learning model. (3) Learning outcome of social studies who learned by Problem-Based Learning model was higher than those studied by the Project-Based Learning model. (4) Learning outcome of social studies who learn by Inquiry model was higher than those studied by the Project-Based Learning model

\section{PENDAHULUAN}

Kurikulum merupakan acuan dasar proses pembelajaran di sekolah untuk mencapai tujuan pendidikan. Sesuai yang tertulis dalam Undang-Undang no. 20 Tahun 2003 pasal 36 tentang sistem pendidikan 
nasional yaitu kurikulum dikembangkan dengan mengacu pada standar Nasional Pendidikan untuk mewujudkan tujuan pendidikan Nasional. Sedangkan dalam Undang-Undang no. 20 Tahun 2003 pasal 38 tentang sistem Pedidikan Nasional menjelaskan tentang kerangka dasar dan struktur kurikulum pendidikan dasar dan menengah ditetapkan oleh pemerintah. Pada tahun 2013 pemerintah telah mengeluarkan peraturan terkait dengan perkembangan kurikulum.

Pemerintah mengeluarkan peraturan tentang kurikulum 2013 yang akan digunakan sebagai acuan untuk melaksakan pembelajaran. Hal ini sesuai yang diatur dalam peraturan Peraturan Menteri Pendidikan Dan Kebudayaan Republik Indonesia Nomor 58 Tahun 2014 pasal 1, Tentang Kurikulum 2013 Sekolah Menengah Pertama/Madrasah Tsanawiyah yaitu Kurikulum pada Sekolah Menengah Pertama/Madrasah Tsanawiyah yang telah dilaksanakan sejak tahun ajaran 2013/2014 disebut Kurikulum 2013 Sekolah Menengah Pertama/Madrasah Tsanawiyah.

Kurikulum 2013 mempunyai karakteritik yaitu proses pembelajarannya dengan menggunakan pedekatan ilmiah (saintific). Sesuai dengan Peraturan Menteri Pendidikan dan Kebudayaan No. 103 Tahun 2014 Tentang Pembelajaran Sekolah Dasar Dan Sekolah Menegah yaitu pendekatan pembelajaran menggunakan pendeketan saintific/pendekatan berbasis proses keilmuan. Menurut Gustin secara kualitatif bahwa pelaksanaan pembelajaran dengan pendekatan saintifik sudah sangat baik hal tersebut dapat dilihat dari pelaksanaan dari langkah-langkah dalam pendekatan saintifik dilakukan sesuai dengan tahap-tahap, baik itu dari kegiatan mengamati, menanya, mengumpulkan informasi, mengasosiasi/mengolah informasi/menalar dan mengkomunikasikan.

Penerapan kurikulum 2013 dengan menggunakan pendekatan saintifik belum berjalan secara maksimal. Penerapan kurikulum 2013 belum berjalan maksimal ditunjukan pada pemberlakuan kembali kurikulum tahun 2006. Hal tersebut sesuai dengan keluarnya Peraturan Menteri Pendidikan nomor 160 tahun 2014 tentang Pemberlakuan Kurikulum Tahun 2006 Dan Kurikulum 2013. Dengan peraturan yang dikeluarkan oleh Menteri tersebut akan membuat para guru kurang maksimal dalam melaksanakan proses pembelajaran di lembaga sekolah.

Salah satu mata pembelajaran di SMP/MTs adalah Ilmu Pengetahuan Sosial (IPS). Melalui pembelajaran IPS dapat diharapkan dapat mengembangkan kemampuan dan sikap rasional terhadap gejala-gejala sosial, serta kemampuan tentang perkembangan masyarakat Indonesia dan masyarakat dunia di masa lampau dan masa kini (Usman, 2004, p.108). IPS merupakan pembelajaran terintegrasi dari beberapa disiplin ilmu, yaitu geografi, sosiologi, sejarah, ekonomi dan antropologi yang dikemas dalam suatu tema-tema tertentu.

Pembelajaran IPS penting dalam berlatih untuk berpikir logis dan kritis, inkuiri, memecahkan masalah, dan ketrampilan dalam kehidupan sosial tetapi pembelajaran IPS seringkali dianggap kurang penting oleh para siswa. Supardi mengatakan bahwa kesalahan presepsi yang terjadi dilapangan anggapan pelajaran ilmu sosial itu pelajaran hafalan, sehingga pelajaran ilmu sosial adalah nomor dua dan model pembelajaran yang dipakai oleh guru masih belum menarik siswa untuk lebih aktif (Supardi, 2011, p.180). Jika guru tidak ada inovasi dalam merencakan model pembelajaran yang efektif maka proses pembelajarannya akan kurang maksimal dalam mencapai tujuan pembelajaran IPS.

Model Pembelajaran IPS dengan pendekatan saintifik yang direkomendasikan dari Kurikulum 2013 belum seluruhnya digunakan secara maksimal, hal itu ditunjukan di SMP 1 Imogiri yang kurang aktif dalam proses pembelajaran dan pencapaian hasil belajar masih belum maksimal. Selain itu guru belom maksimal menerapkan model pembelajaran saintifik.

Model pembelajaran yang sesuai dengan karakteristik siswa diharapkan dapat memperbaiki kualitas pembelajaran IPS 
yang ada di kelas. Beberapa model yang yang direkomendasikan di dalam standar proses untuk memperkuat penerapan pendekatan saintific di dalam kelas diantaranya adalah model Problem Based learning, Project Based Learning dan Inquiry. Ketiga model tersebut diharapkan dapat membangkitkan semangat siswa agar lebih tertarik pada pembelajaran IPS yang selama ini dianggap kurang penting. Selain itu penerapan model tersebut diharapkan dapat meningkatkan hasil belajar siswa.

Berdasarkan uraian diatas tersebut peneliti terdorong untuk melakukan eksperimen tentang efektifitas model pembelajaran Problem Based learning, Project Based Learning dan Inquiry dengan pendekatan saintifik untuk meningkatkan hasil belajar IPS di SMP Kabupaten Bantul Daerah Istimewa Yogyakarta.

\section{METODE PENELITIAN}

Jenis penelitian ini adalah quasi experiment (eksperimen semu) yang dimaksudkan untuk melihat akibat dari suatu perlakuan. Perlakuan itu berupa tindakan tertentu yang dilakukan peneliti terhadap kelompok eksperimen, di mana tindakan tersebut diteliti pengaruhnya. Penelitian ini dikatakan eksperimen semu karena peneliti tidak mengontrol semua variabel-variabel luar yang mempengaruhi pelaksanaan eksperimen.

Penelitian ini menggunakan 3 kelompok eksperimen yaitu kelompok dengan model Problem Based Learning $(P B L)$, Project Based Learning, Inquiry. Tiga perlakuan diberikan kepada 3 kelas dengan sekolah yang berbeda. Masingmasing sekolah dipilih satu kelas yang akan diberi perlakuan. Perlakuan pertama adalah penggunaan model Problem Based Learning $(P B L)$ dalam pembelajaran IPS, perlakuan yang kedua adalah penggunaan model Project Based Learning, perlakuan ketiga adalah penggunaan model Inquiry

Desain penelitian yang digunakan adalah desain Randomized Pretest-Posttest Comparison Group Design. Dapat dijelaskan bahwa ada 3 kelompok dalam pembelajaran IPS yaitu kelompok Acak A dengan model Problem Based Learning, kelompok Acak B dengan Model Project Based Learning, kelompok Acak $\mathrm{C}$ dengan model Inquiry.

Variabel bebas (indepedent variabel) yaitu model pembelajaran. Variabel bebas divariasi dengan tiga model pembelajaran yaitu model Problem Based Learning $(P B L)$, Project Based Learning (PJBL), Inquiry.

Penelitian dilaksanakan di tiga SMP Negeri di Kabupaten Bantul pada semester genap tahun ajaran 2016/2017 pada bulan Februari 2016 s.d. Maret 2016. Pemilihan lokasi sekolah didasarkan pada kriteria sekolah dengan kemampuan siswa dalam standar ketuntasan belajar IPS yang belum maksimal yaitu belum mencapai diatas ratarata $72(\mathrm{KKM})$. Hasil observasi dan wawancara dengan beberapa guru IPS di ketiga sekolah tersebut, ketiganya mempunyai karakteristik yang sama dan sama-sama menerapkan kurikulum 2013. Adanya alasan tersebut maka dipilih menjadi lokasi penelitian.

Populasi dalam penelitian ini semua SMP Negeri di Kabupaten Bantul yang menggunakan Kurikulum 2013, keseluruhannya berjumlah 6 SMP. SMP Negeri di Kabupaten Bantul tersebut diambil sampel 3 sekolah. Dalam pengambilan sampel peneliti mencampur subjek-subjek di dalam populasi sehingga semua subjek dianggap sama. Dengan demikian peneliti memberi hak yang sama kepada setiap subjek untuk memperoleh kesempatan dipilih menjadi sampel.

Berdasarkan teknik sampel Purposive Random Sampling dipilih tiga SMP Negeri di Kabupaten Bantul yaitu SMP Negeri 1 Imogiri, SMP Negeri 1 Sewon dan SMP N 3 Bantul. Ketiga SMP Negeri ini memiliki beberapa kesamaan, salah satunya adalah sama-sama SMP Negeri yang menerapkan Kurikulum 2013 dan sama-sama terakreditasi A. Selain itu kondisi fasilitas pembelajaran di ketiga sekolah kurang lebih sama. Tahap selanjutnya adalah menentukan kelas yang akan dijadikan kelas eksperimen dan menentukan model pembelajaran yang akan diterapkan pada kelas yang telah dipilih dengan undian (Suharsimi, 2013, p.183). 
Teknik pengumpulan data dilakukan dengan 2 teknik, yaitu 1) Tes dalam penelitian ini digunakan untuk mengetahui hasil belajar siswa ditinjau dari pengetahuan setelah diterapkannya model Problem Based Learning (PBL), Project Based Learning (PS, dan Inquiry di SMP Negeri 1 Imogiri, SMP Negeri 1 Sewon, SMP dan SMP N 3 Bantul. 2) Observasi merupakan salah satu penilaian yang dilakukan secara berkesinambungan dengan menggunakan indera, baik secara langsung maupun tidak langsung dengan menggunakan intrumen yang berisi sejumlah indikator yang diamati. Observasi dilakukan oleh guru dan peneliti untuk melakukan penilaian sikap dan keterampilan.

Instrumen yang digunakan adalah tes hasil belajar IPS pada aspek pengetahuan, lembar penilaian diri pada aspek sikap dan instrumen penilaian keterampilan pada aspek keterampilan. Tes hasil belajar IPS pada aspek pengetahuan berisi soal-soal essay. Kualitas instrumen perlu ditinjau aspek kelayakannya, apakah soal-soal tersebut memenuhi persyaratan validitas.

Validitas instrumen dalam penelitian ini diukur dengan menggunakan validitas logis. Validitas logis, berkaitan dengan validitas isi (content validity) dan validitas konstruk (construct validity) yang akan divalidasi oleh ahli (expert judgment). Penyusunan instrumen yang akan divalidasi oleh tim ahli terlebih dulu harus mendapatkan persetujuan dari pembimbing. Validitas instrumen tes hasil belajar, lembar obsevasi serta instrumen penilaian keterampilan dilakukan dengan melakukan konsultasi dengan ahli materi (expert judgment), pembimbing, dan kepada guru yang bersangkutan.

Tujuan validasi instrumen dalam penelitian ini adalah untuk mendapatkan masukan dari ahli terkait kekurangan instrumen hasil belajar IPS baik instrumen untuk penilaian pengetahuan, lembar observasi, dan instrumen penilaian keterampilan. Instrumen penilaian pengetahuan berupa tes dengan soal uraian yang berjumlah 4 soal. Validasi instrumen tes pengetahuan dimulai dari kisi-kisi soal hingga pada aspek penilaian materi. Masukan tersebut kemudian dianalisis dan digunakan untuk merevisi instrumen hasil belajar IPS yang akan digunakan untuk pengambilan data penelitian. Instrumen tes ini berupa soal uraian sehingga tidak memerlukan uji coba di lapangan sebelum penelitian, cukup masukan dari ahli untuk validasi soal.

Validasi untuk instrumen penilaian sikap sudah melalui validasi ahli dan masukan yang sebelumnya telah diberikan oleh ahli digunakan untuk merevisi instrumen penilaian sikap yang akan digunakan untuk pengambilan data. Instrumen sikap ini berupa lembar observasi sehingga tidak memerlukan uji coba di lapangan sebelum penelitian, cukup masukan dari ahli untuk validasi instrumen.

Instrumen penilaian keterampilan dilaksanakan dengan tes kinerja dalam bentuk proyek pembuatan portofolio terkait materi IPS pada sifat dan bentuk Interkasi Sosial sebagai Modal Pembangunan.

Pada pengukuran reliabilitas menggunakan koefisien Alpha Cronbach instrumen tes dilakukan hanya pada satu waktu (one shoot) maka instrumen dikatakan reliabel jika nilai Cronbach Alpha lebih besar dari 0,60

Berdasarkan hasil konsultasi dengan expert judgment menyatakan bahwa soal sejumlah 4 butir uraian sudah valid. Soalsoal yang sudah dinyatakan reliabel sudah melalui beberapa perubahan sesuai dengan saran yang diberikan dari ahli, sehingga dapat dinyatakan bahwa instrumen tes tersebut layak digunakan untuk penelitian.

Berdasarkan analisis data uji reliabilitas butir soal tes diperoleh hasil analisis bahwa instrumen dinyatakan reliabel karena koefisien alpha lebih dari 0 , 60 yaitu 0, 714. Kesimpulannya adalah instrumen tes hasil belajar IPS telah memenuhi kriteria valid dan reliabel, sehingga dapat dinyatakan bahwa instrumen tersebut telah layak digunakan untuk penelitian. Setelah melakukan beberapa kali eksperimen dilakukan penilaian pengetahuan, penilaian sikap, dan penilaian keterampilan. Hasil akhir semua penilaian 
merupakan data hasil belajar IPS yang digunakan untuk menguji hipotesis penelitian. Data hasil belajar IPS untuk mengetahui apakah ada perbedaan antara hasil belajar IPS pada tiap model yang dianalisis melalui tiga tahapan antara lain: 1) Deskripsi Data yaitu Tahap deskripsi data meliputi membuat tabulasi data validasi ahli, tabulasi data untuk setiap variabel, mengurutkan data secara interval dan menyusunnya dalam bentuk tabel distribusi frekuensi, mencari median, rata-rata (mean), dan simpangan baku, 2) Uji prasyarat analisis yaitu uji Uji Normalitas yaitu uji Kolmogorof-Smirnov $\quad(K-S)$. Uji ini digunakan untuk mengetahui apakah sampel yang digunakan untuk penelitian ini berasal dari populasi yang berdistribusi normal atau tidak dan Uji homogenitas varians dilakukan menggunakan Levene-Test. Uji homogenitas yang dipakai bertujuan untuk mengetahui homogenitas varians untuk masing-masing kelas yang dibandingkan yaitu kelas eksperimen Model Problem Based Learning, kelas eksperimen Project Based Learning dan kelas eksperimen Inquiry, 3) Uji Hipotesis, pengujian hipotesis pada penelitian ini menggunakan analisis varian satu jalur (One Way Anova). Analisis varian satu jalur digunakan untuk menganalisis keefektifan model Problem Based Learning (PBL), Project Based Learning dan Inquiry yang ditinjau dari hasil belajar IPS.

\section{HASIL \\ PENELITIAN \\ PEMBAHASAN \\ Data Hasil Belajar SMP 1 Sewon \\ Data Hasil Belajar IPS Postes Aspek Pengetahuan Kelas Eksperimen Problem Based Learning}

Untuk menentukan jumlah kelas interval digunakan rumus yaitu jumlah kelas $=1+3,3 \log \mathrm{n}$, dimana $\mathrm{n}$ adalah jumlah siswa atau responden. Dari perhitungan diketahui bahwa $\mathrm{n}=24$ sehingga diperoleh banyak kelas $1+3.3 \log 27=5,55$ dibulatkan menjadi 6 kelas interval. Rentang data dihitung dengan rumus nilai maksimal - nilai minimal +1 , sehingga diperoleh rentang data sebesar $3,80-2,40=0,30$. Sedangkan panjang kelas interval yaitu rentang/jumlah kelas, sehingga menghasilkan panjang kelas 0,30/5,55=1,8.

Ringkasan hasil belajar IPS SMP N 1 Sewon setelah mendapatkan perlakuan eksperimen Problem Based Learning dapat dijabarkan sebagai berikut.

Tabel 1. Kelas Interval Hasil Belajar IPS

Postes Aspek Pengetahuan kelas Eksperimen PBL

\begin{tabular}{cccc}
\hline No & Interval & Frekuensi & Persentase \\
\hline 1 & $3,68-3,86$ & 1 & 4,2 \\
2 & $3,49-3,67$ & 9 & 37,5 \\
3 & $3,30-3,48$ & 7 & 29,2 \\
4 & $3,11-3,29-$ & 2 & 8,3 \\
5 & $2,92-3,10$ & 3 & 12,5 \\
6 & $2,73-2,91$ & 2 & 8,3 \\
& Jumlah & 24 & 100 \\
\hline
\end{tabular}

Sumber: Data Hasil Penelitian, 2016

Data Hasil Belajar IPS Postes Aspek Sikap Kelas Eksperimen Problem Based Learning

Untuk menentukan jumlah kelas interval digunakan rumus yaitu jumlah kelas $=1+3,3 \log n$, dimana $n$ adalah jumlah siswa atau responden. Dari perhitungan diketahui bahwa $\mathrm{n}=24$ sehingga diperoleh banyak kelas $1+3.3 \log 27=5,55$ dibulatkan menjadi 6 kelas interval. Rentang data dihitung dengan rumus nilai maksimal - nilai minimal +1 , sehingga diperoleh rentang data sebesar $3,80-2,73=1,07$. Sedangkan panjang kelas interval yaitu rentang/jumlah kelas, sehingga menghasikan panjang kelas 1,07/5,55=0,18.

Ringkasan hasil belajar IPS pada aspek sikap SMP N 1 Sewon setelah mendapatkan perlakuan eksperimen model Problem Based Learning dapat dijabarkan sebagai berikut.

Tabel 2. Kelas Interval Hasil Belajar IPS Postes Aspek Sikap Kelas Eksperimen PBL

\begin{tabular}{cccc}
\hline No & Interval & Frekuensi & Persentase \\
\hline 1 & $3,70-3,87$ & 1 & 3,1 \\
2 & $3,52-3,69$ & 3 & 9,4 \\
3 & $3,34-3,51$ & 16 & 50,0 \\
4 & $3,16-3,33$ & 6 & 18,8 \\
5 & $2,98-3,15$ & 3 & 9,4 \\
6 & $2,80-2,97$ & 3 & 9,4 \\
& Jumlah & 32 & 100 \\
\hline
\end{tabular}

Sumber: Data Hasil Penelitian, 2016 
Data Hasil Belajar IPS Postes Aspek Keterampilan Kelas Eksperimen Problem Based Learning

Untuk menentukan jumlah kelas interval digunakan rumus yaitu jumlah kelas $=1+3,3 \log \mathrm{n}$, dimana $\mathrm{n}$ adalah jumlah siswa atau responden. Dari perhitungan diketahui bahwa $\mathrm{n}=24$ sehingga diperoleh banyak kelas $1+3.3 \log 24=5,55$ dibulatkan menjadi 6 kelas interval. Rentang data dihitung dengan rumus nilai maksimal - nilai minimal +1 , sehingga diperoleh rentang data sebesar $3,43-2,71=0,7$. Sedangkan panjang kelas interval yaitu rentang/jumlah kelas, sehingga menghasilkan panjang kelas 0,7/5,55=0,12.

Ringkasan hasil belajar IPS pada aspek Keterampilan SMP N 1 Sewon setelah mendapatkan perlakuan eksperimen model Problem Based Learning dapat dijabarkan sebagai berikut.

Tabel 3. Kelas Interval Hasil Belajar IPS Postes Aspek Keterampilan kelas Eksperimen PBL

Data Hasil Belajar IPS SMP Negeri 1 Imogiri

\begin{tabular}{cccc}
\hline No & Interval & Frekuensi & Persentase \\
\hline 1 & $3,55-3,83$ & 7 & 29,2 \\
2 & $3,24-3,54$ & 4 & 16,7 \\
3 & $2,93-3,23$ & 3 & 12,5 \\
4 & $2,62-2,92$ & 3 & 12,5 \\
5 & $2,31-2,61$ & 6 & 25,0 \\
6 & $2,00-2,30$ & 1 & 4,2 \\
& Jumlah & 24 & 100 \\
\hline
\end{tabular}

Sumber: Data Hasil Penelitian, 2016

\section{Data Hasil Belajar IPS Postes pada Aspek Pengetahuan kelas Eksperimen Project Based Learning}

Untuk menentukan jumlah kelas interval digunakan rumus yaitu jumlah kelas $=1+3,3 \log \mathrm{n}$, dimana $\mathrm{n}$ adalah jumlah siswa atau responden. Dari perhitungan diketahui bahwa $\mathrm{n}=32$ sehingga diperoleh banyak kelas $1+3.3 \log 32=5,967$ dibulatkan menjadi 6 kelas interval. Rentang data dihitung dengan rumus nilai maksimal - nilai minimal +1 , sehingga diperoleh rentang data sebesar 3,80-2,20 = 1,6. Sedangkan panjang kelas interval yaitu rentang/jumlah kelas, sehingga menghasilkan panjang kelas $1,65 / 5,967=$ 0,27 .

Ringkasan hasil belajar SMP N 1 Imogiri pada aspek pengetahuan dapat dijabarkan sebagai berikut.

Tabel 4. Kelas Interval Hasil Postes Pada

Aspek Pengetahuan kelas Eksperimen Project Based Learning

\begin{tabular}{cccc}
\hline No & Interval & Frekuensi & Persentase \\
\hline 1 & $3,36-3,48$ & 10 & 41,7 \\
2 & $3,23-3,35$ & 4 & 16,7 \\
3 & $3,10-3,22$ & 4 & 16,7 \\
4 & $2,97-3,09$ & 0 & 0 \\
5 & $2,84-2,96$ & 3 & 12,5 \\
6 & $2,71-2,83$ & 3 & 12,5 \\
& Jumlah & 24 & 100 \\
\hline
\end{tabular}

Sumber: Data Hasil Penelitian, 2016

Data Hasil Belajar IPS Postes pada Aspek
Sikap kelas Eksperimen Project Based
Learning
Untuk menentukan jumlah kelas interval digunakan rumus yaitu jumlah kelas $=1+3,3 \log \mathrm{n}$, dimana $\mathrm{n}$ adalah jumlah siswa atau responden. Dari perhitungan diketahui bahwa $n=32$ sehingga diperoleh banyak kelas $1+3.3 \log 32=5,967$ dibulatkan menjadi 6 kelas interval. Rentang data dihitung dengan rumus nilai maksimal - nilai minimal +1 , sehingga diperoleh rentang data sebesar 3,80-2,80 = 1 . Sedangkan panjang kelas interval yaitu rentang/jumlah kelas, sehingga menghasikan panjang kelas $1 / 5,967=0,17$.

Ringkasan hasil belajar IPS Postes SMP N 1 Imogiri pada Aspek sikap dapat dijabarkan sebagai berikut.

Tabel 5. Kelas Interval Hasil Postes Pada Aspek Sikap kelas Eksperimen Project Based Learning

\begin{tabular}{lrcc}
\hline No & Interval & Frekuensi & Persentase \\
\hline 1 & $3,25-3,49$ & 8 & 25,0 \\
2 & $3,00-3,24$ & 7 & 21,9 \\
3 & $2,75-2,99$ & 4 & 12,5 \\
4 & $2,50-2,74$ & 10 & 31,3 \\
5 & $2,25-2,49$ & 1 & 3,1 \\
6 & $2,00-2,24$ & 2 & 6,3 \\
\multicolumn{2}{l}{ Jumlah } & 32 & 100 \\
\hline
\end{tabular}

Sumber: Data Hasil Penelitian, 2016

Data Hasil Belajar IPS Postes pada Aspek Keterampilan kelas Eksperimen Project Based Learning 
Untuk menentukan jumlah kelas interval digunakan rumus yaitu jumlah kelas $=1+3,3 \log \mathrm{n}$, dimana $\mathrm{n}$ adalah jumlah siswa atau responden. Dari perhitungan diketahui bahwa $\mathrm{n}=32$ sehingga diperoleh banyak kelas $1+3.3 \log 32=5,967$ dibulatkan menjadi 6 kelas interval. Rentang data dihitung dengan rumus nilai maksimal - nilai minimal +1 , sehingga diperoleh rentang data sebesar 3,43-2,00 =1,43. Sedangkan panjang kelas interval yaitu rentang/jumlah kelas, sehingga menghasilkan panjang kelas 1,43/5,967 = 0,24 .

Ringkasan hasil belajar IPS Postes SMP N 1 Imogiri pada Aspek keterampilan dapat dijabarkan sebagai berikut.

Tabel 6. Kelas Interval Hasil Postes Pada

Aspek Keterampilan kelas Eksperimen

Project Based Learning

\begin{tabular}{lccc}
\hline No & Interval & Frekuensi & Persentase \\
\hline 1 & $3,60-3,87$ & 6 & 18,8 \\
2 & $3,32-3,59$ & 3 & 9,4 \\
3 & $3,04-3,31$ & 7 & 21,9 \\
4 & $2,76-3,03$ & 6 & 18,8 \\
5 & $2,48-2,75$ & 5 & 15,6 \\
6 & $2,20-2,47$ & 5 & 15,6 \\
\multicolumn{5}{l}{ Jumlah } & 32 & 100 \\
\hline
\end{tabular}

Sumber: Data Hasil Penelitian, 2016

SMP Negeri 3 Bantul

Data Hasil Belajar IPS Postes Pada Aspek Pengetahuan Kelas Eksperimen Model Inquiry

Untuk menentukan jumlah kelas interval digunakan rumus yaitu jumlah kelas $=1+3,3 \log \mathrm{n}$, dimana $\mathrm{n}$ adalah jumlah siswa atau responden. Dari perhitungan diketahui bahwa $\mathrm{n}=27$ sehingga diperoleh banyak kelas $1+3.3 \log 27=5,72$ dibulatkan menjadi 6 kelas interval. Rentang data dihitung dengan rumus nilai maksimal - nilai minimal +1 , sehingga diperoleh rentang data sebesar 3,80-2,40 =1,40. Sedangkan panjang kelas interval yaitu rentang/jumlah kelas, sehingga menghasilkan panjang kelas 1,40/5,72= 0,23 .

Ringkasan hasil belajar IPS pada aspek pengetahuan SMP N 3 Bantul dapat dijabarkan sebagai berikut.
Tabel 7. Kelas Interval Hasil belajar IPS

Postes Aspek Pengetahuan kelas Eksperimen Inquiry

\begin{tabular}{lccc}
\hline No & Interval & Frekuensi & Persentase \\
\hline 1 & $3,79-3,91$ & 1 & 3,7 \\
2 & $3,66-3,78$ & 0 & 0,0 \\
3 & $3,53-3,65$ & 6 & 22,2 \\
4 & $3,40-3,39$ & 12 & 44,4 \\
5 & $3,27-3,39$ & 4 & 14,8 \\
6 & $3,14-3,26$ & 4 & 14,8 \\
\multicolumn{2}{l}{ Jumlah } & 27 & 100 \\
\hline \multicolumn{2}{l}{ Suln }
\end{tabular}

Sumber: Data Hasil Penelitian, 2016

Data Hasil Belajar IPS Postes Pada Aspek Sikap Kelas Eksperimen Model Inquiry

Untuk menentukan jumlah kelas interval digunakan rumus yaitu jumlah kelas $=1+3,3 \log n$, dimana $n$ adalah jumlah siswa atau responden. Dari perhitungan diketahui bahwa $\mathrm{n}=27$ sehingga diperoleh banyak kelas $1+3.3 \log 27=5,72$ dibulatkan menjadi 6 kelas interval. Rentang data dihitung dengan rumus nilai maksimal - nilai minimal +1 , sehingga diperoleh rentang data sebesar 3,80-2,93 $=0,87$. Sedangkan panjang kelas interval yaitu rentang/jumlah kelas, sehingga menghasilkan panjang kelas 0,87/5,72= 0,14 .

Ringkasan hasil belajar IPS pada aspek Sikap SMP N 3 Bantul dapat dijabarkan sebagai berikut.

Tabel 8. Kelas Interval Hasil belajar IPS

Postes Aspek Sikap kelas Eksperimen

\begin{tabular}{lrcc}
\multicolumn{4}{c}{ Inquiry } \\
\hline No & Interval & Frekuensi & Persentase \\
\hline 1 & $3,60-3,83$ & 8 & 29,6 \\
2 & $3,36-3,59$ & 4 & 14,8 \\
3 & $3,12-3,35$ & 5 & 18,5 \\
4 & $2,88-3,11$ & 4 & 14,8 \\
5 & $2,64-2,87$ & 2 & 7,4 \\
6 & $2,40-2,63$ & 4 & 14,8 \\
\multicolumn{5}{l}{ Jumlah } & 27 & 100
\end{tabular}

Sumber: Data Hasil Penelitian, 2016

Data Hasil Belajar IPS Postes Pada Aspek Keterampilan Kelas Eksperimen Model Inquiry.

Untuk menentukan jumlah kelas interval digunakan rumus yaitu jumlah kelas $=1+3,3 \log \mathrm{n}$, dimana $\mathrm{n}$ adalah jumlah siswa atau responden. Dari perhitungan 
diketahui bahwa $\mathrm{n}=27$ sehingga diperoleh banyak kelas $1+3.3 \log 27=5,72$ dibulatkan menjadi 6 kelas interval. Rentang data dihitung dengan rumus nilai maksimal - nilai minimal +1 , sehingga diperoleh rentang data sebesar 3,86-3,14=0,27. Sedangkan panjang kelas interval yaitu rentang/jumlah kelas, sehingga menghasilkan panjang kelas 0,27/5,72= 0,12 .

Ringkasan hasil belajar IPS pada aspek Keterampilan SMP N 3 Bantul dapat dijabarkan sebagai berikut.

Tabel 9. Kelas Interval Hasil belajar IPS

Postes Aspek Keterampilan kelas Eksperimen Inquiry

\begin{tabular}{lrll}
\hline No & Interval & Frekuensi & Persentase \\
\hline 1 & $3,68-3,82$ & 3 & $11,1 \%$ \\
2 & $3,53-3,67$ & 16 & $59,3 \%$ \\
3 & $3,38-3,52$ & 4 & $14,8 \%$ \\
4 & $3,23-3,37$ & 1 & $3,7 \%$ \\
5 & $3,08-3,32$ & 0 & $0 \%$ \\
6 & $2,93-3,07$ & 3 & $11,1 \%$ \\
\multicolumn{2}{l}{ Jumlah } & 27 & $100 \%$ \\
\hline
\end{tabular}

Sumber: Data Hasil Penelitian, 2016

\section{Uji Normalitas}

Semua nilai K-S Z memiliki sig $>0,05$. Pada kelas eksperimen Problem Based Learning menghasilkan Hasil belajar IPS sebelum perlakuan memiliki nilai signifikansi 0,389 dan hasil belajar IPS setelah perlakuan memiliki nilai signifikansi 0,792. Pada kelas eksperimen Project Based Learning menghasilkan Hasil belajar IPS sebelum perlakuan memiliki nilai signifikansi 0,787 dan hasil belajar IPS setelah perlakuan memiliki nilai signifikansi 0,951. Pada kelas eksperimen Inquiry menghasilkan Hasil belajar IPS sebelum perlakuan memiliki nilai signifikansi 0,678 dan hasil belajar IPS setelah perlakuan memiliki nilai signifikansi 0,892 . Artinya ketiga kelas eksperimen tersebut memiliki sig $>0,05$ artinya data ketiganya berasal dari populasi yang terdistribusi normal.

Berdasarkan analisis tersebut semua pengelompokan sampel dalam penelitian ini berasal dari populasi yang terdistribusi normal karena nilai signifikansinya lebih dari 0,05 untuk setiap kelompok eksperimen yang diukur atau menerima hipotesis nol.
Artinya asumsi distribusi normal terpenuhi dan perlu dilanjutkan pada asumsi kedua yaitu homogenitas variansi.

Uji Homogenitas

Semua nilai F pada memiliki sig $>0,05$. Hasil belajar IPS sebelum perlakuan memiliki nilai $\mathrm{F}$ dengan signifikansi sebesar 0,338 sedangkan nilai hasil Belajar IPS setelah perlakuan memiliki nilai 0,778 .

Jika Levene-Test memiliki sig $<0,05$ grup memiliki varian yang berbeda dan hal ini menyalahi asumsi. Jadi yang dikehendaki adalah grup tidak memiliki varian yang berbeda $(>0,05)$. Hasil diatas memiliki kesimpulan bahwa semua pengelompokan sampel dalam penelitian ini memiliki variansi yang homogen karena memiliki sig $>0,05$. Artinya asumsi homogenitas dalam penelitian ini terpenuhi. Setelah semua asumsi/prasyarat analisis terpenuhi, maka dapat dilakukan uji hipotesis

Uji Hipotesis 1

Nilai signifikasi $0,000<0,05$, berarti hipotesis nihil pertama dalam penelitian ini ditolak. Hal ini berarti Terdapat perbedaan hasil belajar IPS antara yang belajar dengan menggunakan model Problem Based Learning, Project Based Learning, dan Inquiry di SMP Kabupaten Bantul.

Uji Hipotesis 2

Nilai statistik uji F dengan signifikansi $0,005<0,05$ berarti hipotesis nihil kedua dalam penelitian ini ditolak. Artinya Hasil belajar siswa IPS yang belajar dengan model Inquiry lebih tinggi dibandingkan yang belajar dengan model Problem Based Learning di SMP Kabupaten Bantul.

\section{Uji Hipotesis 3}

Nilai uji $F$ dengan sig $=0,007$ berarti hipotesis nol ketiga dalam penelitian ini ditolak. Hasil uji $\mathrm{F}$ diperoleh nilai $F_{\text {hitung }}$ sebesar 7,770. Jika dibandingkan dengan nilai $\mathrm{F}_{\text {tabel }}$ (terlampir) pada taraf signifikansi $5 \%$, maka $F_{\text {hitung }}>F_{\text {tabel }}(7,770>3,04)$, sehingga nilai tersebut signifikan. Artinya Hasil belajar siswa IPS yang belajar dengan model Problem Based Leaning lebih tinggi dibandingkan yang belajar dengan model Project Based Learning di SMP Kabupaten Bantul.

Uji Hipotesis 4 
Nilai statistik uji $F$ dengan signifikansi $0,000<0,05$ berarti hipotesis nihil keempat dalam penelitian ini ditolak. Artinya Hasil belajar siswa IPS yang belajar dengan model Inquiry lebih tinggi daripada yang belajar dengan model Project Based Learning di SMP Kabupaten Bantul.

\section{KESIMPULAN Simpulan}

Dari pembahasan penelitian ini dapat disimpulkan bahwa: 1) Terdapat perbedaan hasil yang signifikan antara belajar IPS dengan model Problem Based learning, Project Based Learning, dan Inquiry Discovery, 2) hasil belajar siswa dengan model Inquiry lebih tinggi dibandingkan dengan model Problem Based Learning, 3) hasil belajar siswa dengan model Problem Based Leaning lebih tinggi dibandingkan dengan model Project Based Learning, 4) hasil belajar siswa yang belajar dengan model Inquiry lebih tinggi dibandingkan yang belajar dengan model Project Based Learning.

\section{Saran}

Dari simpulan diatas, peneliti dapat merikan saran sebagai berikut: 1) dalam melaksanakan pembelajaran IPS khususnya SMP Negeri di Kabupaten Bantul yang menggunakan Kurikulum 2013 hendaklah guru IPS mengaplikasikan model Problem Based learning, Project Based Learning, dan Inquiry. Hal tersebut karena dari ketiga model itu terbukti efektif memberikan hasil belajar IPS yang berbeda pada materi tema 4: keragaman Sosial Budaya sebagai Modal Dasar Pembangunan dan sub tema pada sifat dan bentuk interaksi sosial budaya dalam pembangunan. Selain itu materi itu kemungkinan besar juga akan memberikan hasil yang maksimal sesuai tujuan pembelajaran. Karena ketiga model tersebut memiliki sifat berbasis masalah yang sesuai dengan tujuan pembelajaran IPS .2) Guru menggunakan salah satu model Pembelajaran yang efektif sesuai dengan materi dan karakteristik siswanya untuk memberikan hasil belajar yang maksimal. 3) Sebaiknya guru IPS menerapkan model Problem Based learning, Project Based
Learning, dan Inquiry pada kondisi siswa yang kondusif atau diterapkan pada pagi hari agar lebih maksimal. Akan tetapi ketiga model tersebut bukan berarti tidak dapat digunakan pada siang hari. Apabila guru menggunakan model tersebut pada siang hari lebih baik dikombinasi dengan metode pembelajaran yang bersifat permainan. Sehingga siswa tidak terlalu tenggang dalam mengikuti pembelajaran. 4) Ketiga model tersebut berbasis masalah untuk melatih siswa untuk kerja sama yang positif antar siswa sehingga mampu menambah pengetahuan dan pemahaman siswa terkait materi yang disampaikan guru. Oleh karena itu penerapan dari ketiga model tersebut digunakan setiap kali pertemuan secara bergantian agar melatih siswa lebih kritis dalam mengatasi masalah.

\section{DAFTAR PUSTAKA}

Arikunto, Suharsimi.(2013). Prosedur penelitian suatu pendekatan praktik. Jakarta: PT. Rineka Cipta.

Gustin, G., \& Suharno, S. (2015). Evaluasi pembelajaran pendidikan pancasila dan kewarganegaraan dengan pendekatan saintifik. Harmoni Sosial: Jurnal Pendidikan IPS, 2(2), 144-157. Retrieved from http://journal.uny.ac.id/index.php/hsjp i/article/view/7666/6607.

Kemendikbud. (2014). Buku guru ilmu pengetahuan sosial. Jakarta: Kemendikbud.

Kemendiknas. (2013). Peraturan Menteri Pendidikan dan kebudayaan Republik Indonesia Nomor 66 Tahun 2013 tentang standar penilaian pendidikan.

Republik Indonesia. (2013). UndangUndang Republik Indonesia No. 20 Tahun 2003 Tentang Sistem Pendidikan Nasional.

Supardi. (2011). Dasar-dasar ilmu sosial. Yogyakarta: Penerbit Ombak.

Usman, M dan Mandalika. (2011). Menjadi guru profesional. Bandung: PT Remaja Rosdakarya Offset. 